\title{
Os limites da basileia segundo João Crisóstomo: reflexões sobre o tratado 'Uma comparação entre o rei e o monge'
}

\author{
The frailties of 'basileia' according to John Chrysostom: some \\ remarks on the treatise 'A comparison between a king and a monk'
}

Gilvan Ventura da Silva*

RESUMO

Vivendo numa sociedade confrontada amiúde pela ameaça dos persas e dos germanos, João Crisóstomo, ao contrário de seus antecessores, como Eusébio de Cesareia, não concebia o governo do basileus como dotado de qualquer significado religioso especial. O Império Romano, para João, constituía apenas um governo de homens sobre homens resultante de uma eleição. Um governo que, portanto, não se encontrava inscrito na ordem da natureza e nem tampouco comportava elementos místicos, sobrenaturais, visto estar sujeito à corrupção e à degenerescência. Em suas obras, João raramente se refere ao Imperium Christianum e é bastante lacônico ao mencionar os soberanos de seu tempo, o que sugere certo desinteresse pelo tema. Na realidade, o basileus não representava, segundo o autor, o modelo de cristão a ser imitado, distinção que caberia ao monge. Tendo em vista estas considerações, temos por finalidade discutir as características do ofício régio na Antiguidade Tardia, período de consolidação do movimento monástico, à luz do pensamento de João Crisóstomo. Para tanto, exploraremos uma das suas primeiras obras: o tratado Uma comparação entre o rei e o monge, composto no início da década de 370, em Antioquia.Letra

Palavras-chave: Antiguidade Tardia. Antioquia; Basileia. Monacato. João Crisóstomo.

\footnotetext{
- Doutor em História pela Universidade de São Paulo (USP) e Professor de História Antiga da Universidade Federal do Espírito Santo (UFES). Bolsista Produtividade 1-D do CNPq. No momento, executa o projeto de pesquisa intitulado A cidade e os usos do corpo no Império Romano: um olhar sobre a cristianização de Antioquia.
} 


\section{ABSTRACT}

Living in a society under the threat of Persians and Barbarians, John Chrysostom, differently from his predecessors, like Eusebius of Cesarea, did not devise the Graeco-Roman basileia as an institution that bore any special religious meaning. As for him, the Roman Empire was just a gathering of humans governing other humans due to an election; a government that did not arise from a natural basis and did not exhibit any mystical, supernatural capacity, for such government was not geared to linger on. In his works, John Chrysostom seldom mentions the Imperium Chistianum and the emperors of his time, subjects which did not attract his attention. Truth to tell, according to the author, the basileus did not represent a Christian model that should be followed by his contemporaries. Such honor should be bestowed on the monks instead. In light of these remarks, we intend to discuss, in this article, some characteristics of the monarchy in the Late Antiquity, a time span when we witness the flourishing of the monasticism as well. In order to do that, we deal with one of John's first works: the treatise A comparison between a king and a monk, written in Antioch, John's homeland, in the first years of the decade of $370 \mathrm{~A}$. D.

Keyword: Late Antiquity. Antioch; Basileia. Monasticism. John Chrysostom.

\section{João Crisóstomo, discípulo de Eusébio de Cesareia?}

No início do século IV, a súbita aproximação entre um soberano impetuoso que, numa conjuntura de guerra civil, buscava por todos os meios ampliar as suas bases de apoio e os devotos de um culto oriental considerado até então perigoso para a estabilidade da res publica foi um acontecimento, sem dúvida, determinante para a redefinição da maneira pela qual os imperadores lidavam com os assuntos de natureza religiosa, pois, diante da afirmação irreversível de um credo monoteísta, intolerante e proselitista, como era o cristianismo, vemos toda a dinâmica sociorreligiosa do Império Romano tardo-antigo ser rapidamente alterada. Muito embora os exemplos a esse respeito sejam abundantes, bastaria recordar a reabilitação de Jerusalém que, após um longo período de relativo abandono, passa uma vez mais a desempenhar um papel de destaque devido à peregrinação de Helena à Terra Santa por determinação de seu filho, Constantino. Mediante os favores de um monarca desejoso de proclamar sua devoção ao seu novo patrono espiritual, a cidade logo recupera a vitalidade e o protagonismo que por séculos a distinguiram, antes que a revolta desastrosa de Bar Kochba, o Filho da Estrela, entre 132 e 135, levasse Adriano a arrasar a Judeia e a renomear Jerusalém como Élia Capitolina, proibindo desde então o acesso dos judeus à cidade sob pena de morte (MONTEFIORE, 2013). Os atos de benevolência de Constantino para com os cristãos foram à época celebrados como o prenúncio de uma nova era, na qual, mediante o beneplácito imperial, a lgreja poderia exercer de modo mais eficaz sua atividade missionária até o consumar da Parúsia. 
A adesão de Constantino ao cristianismo representou, para os cristãos, uma experiência radicalmente nova, ou seja, a transição de um estado no qual o culto que professavam era visto com suspeita e desagrado por amplas parcelas da sociedade e pelas autoridades públicas para um estado no qual a livre proclamação da Boa Nova não apenas era permitida, mas encorajada pelos próprios imperadores, produzindo-se assim uma simbiose entre Império e Igreja que Melito de Sárdis, já no século II, havia antecipado ao observar a coincidência entre o nascimento de Cristo e a fundação do Principado por Augusto (QUASTEN, 1949, p. 242). Nesse sentido, tanto as leis contidas no Código Teodosiano concedendo privilégios aos cristãos e coibindo a atuação dos seus rivais - judeus, pagãos, maniqueístas e outros -quanto o notável programa edilício de Constantino e sucessores, que em poucas décadas dotam a Igreja de uma arquitetura monumental, uma das faces mais evidentes do processo de cristianização, constituem testemunhos importantes dessa autêntica guinada espiritual que começa a se delinear no dia seguinte à batalha da Ponte Mílvia, em 312. Todavia, se a atuação pró-cristã de Constantino produzia um impacto de intensa magnitude na sociedade romana tardo-antiga, ela, por outro lado, não deixava de gerar incerteza sobre os rumos da própria instituição eclesiástica, que, de refratária aos poderes deste mundo, passava agora à condição de sua mais ilustre colaboradora. Num contexto em que a ingerência da autoridade imperial em assuntos religiosos era considerada um autêntico a priori, como demonstra o controle que os Augustos, na condição de sumos pontífices, sempre tiveram sobre o clero, os cultos e, não menos importante, os recursos dos templos pagãos, os autores cristãos eram desafiados a lidar, da melhor maneira possível, com a pretensão dos imperadores em prolongar essa tradição ao tratarem a Igreja como uma instância dependente e subordinada ao Estado. Num primeiro momento, a resposta a esse dilema foi amplamente favorável às aspirações da casa imperial, como vemos em Eusébio de Cesareia, o expoente da concepção segundo a qual o basileus revestiria uma autoridade calcada na própria tradição veterotestamentária, o que levou o autor, em seu panegírico póstumo a Constantino, a exaltar o imperador como o novo Moisés, cumulando-o de atributos que reforçavam a sacralidade do poder imperial (Vita Constantini I, 12, 1-2; I, 38, 5). Desse modo, Eusébio se converte no principal artífice daquilo que poderíamos qualificar como uma versão cristã da basileia, da realeza sagrada tardo-antiga, cuja construção remonta pelo menos ao governo de Aureliano, ainda no torvelinho da crise sucessória que abalou o Império em meados do século III, tendo recebido um impulso significativo a partir da ação restauradora de Diocleciano.

As inúmeras medidas tomadas por Constantino em prol do cristianismo tornavam praticamente inevitável que os imperadores passassem desde então a ocupar uma posição privilegiada na Igreja e que a eles fosse atribuído algum carisma ou dignidade sobrenatural. O grande problema era delimitar o lugar exato ocupado pelos monarcas: estariam eles supra ou intra Ecclesiam? Poderiam eles intervir ao seu bel prazer em matéria de fé ou teriam os bispos a palavra final? Seriam os imperadores mímesis da divindade judaico-cristã, quase como hipóstases divinas reinando sobre a terra, como parece sugerir Eusébio no De laudibus Constantini (SILVA; MARVILLA, 2006, p. 389), ou apenas líderes humanos encarregados de assegurar a paz a fim de que a lgreja pudesse cumprir a vontade do seu fundador sem maiores obstáculos? A resposta a essas questões variou bastante nos anos que se seguiram a Constantino, de acordo com os propósitos do episcopado e os 
interesses da política imperial, valendo a pena recordar que um soberano claramente intervencionista, como foi Constâncio II, não deixou de suscitar a desconfiança ou mesmo a hostilidade declarada de representantes do clero, em especial daqueles filiados ao credo de Niceia, a exemplo de Ossio de Córdoba, o primeiro bispo a evocar a célebre distinção feita por Jesus entre aquilo que diria respeito a César e aquilo que diria respeito a Deus (DRAKE, 2010, p. 458), argumento que, à época, parecia um tanto ou quanto fora de lugar haja vista a colaboração indispensável dos imperadores para a consolidação institucional da Igreja, incluindo a formação do patrimônio eclesiástico. Mais ousado, no entanto, foi Hilário de Poitiers, outro militante da facção nicena que, num manifesto publicado após 361, denunciava Constâncio II nada mais nada menos como o Anticristo, o inimigo que buscava desfazer a Criação, num ataque sem precedentes à dignidade da própria realeza (SILVA, 2003a). Ao mesmo tempo, Constâncio, apoiado pelos bispos arianos, em especial Valente de Mursa e Ursácio de Singidunum, deflagrava uma ampla reforma episcopal destinada, ao que tudo indica, a colocar o clero cristão a serviço direto da administração imperial (SILVA, 2003, p. 89).

Mesmo diante da constatação de que a capacidade de ingerência dos imperadores sobre a Igreja era, na época tardia, uma realidade bem estabelecida, o assunto não gozava, em absoluto, de consenso, originando amiúde o enfrentamento de setores do episcopado com o poder imperial pela delimitação das esferas de competência civil e eclesiástica, enfrentamento este que, diga-se de passagem, será o combustível de inúmeras querelas político-religiosas por toda a Idade Média. Todavia, como argumenta Drake (2010, p. 460), não se trata aqui de um conflito que implique, a princípio, a separação entre essas duas entidades que são a Igreja e o Império, mas a delimitação do grau de dependência entre ambas, havendo, por um lado, os defensores da primazia do imperador, que, na condição de vicarius Christi, teria competência para submeter o episcopado e, por outro, os defensores de um clero independente e dotado de licentia suficiente para admoestar os próprios soberanos, se necessário. Em termos geográficos, Pasquato (2005, p. 782) sugere a existência de uma inclinação do clero oriental, herdeiro direto da teologia política formulada por Eusébio de Cesareia, em se alinhar com os imperadores, tomando-os, conforme o caso, como líderes supremos da Igreja ou mesmo como emissários divinos para a conversão dos povos, o que desembocará, séculos mais tarde, na experiência teocrática de Justiniano. Já o clero ocidental, em boa parte devido às décadas de luta em defesa do credo de Niceia diante das investidas de Constâncio II, teria conservado uma posição mais independente, a exemplo de Ambrósio, que se negava a admitir que Teodósio pudesse tomar decisões contrárias aos interesses dos cristãos, como vemos no episódio de 388, ocorrido em Calínico, na Síria, quando uma turba de leigos e monges liderada pelo bispo saqueou e incendiou a sinagoga local. Informado do acontecido pelo Comes Orientis, o imperador determina a reconstrução do edifício às expensas do bispo e a punição dos incendiários, o que suscita a reação imediata de Ambrósio, para quem, se a decisão fosse cumprida, os cristãos seriam humilhados diante dos judeus. Por fim, Teodósio capitula, anulando seu veredito anterior (GONZÁLEZ SALINERO, 2000, p. 224). Não obstante a tentativa de esclarecer, em linhas gerais, o comportamento político do episcopado do Oriente e o do Ocidente, esse esquema binário de Pasquato, que pressupõe o alinhamento direto dos bispos orientais com o 
basileus, bem como a resistência aguerrida dos bispos ocidentais à autoridade imperial, não é isento de exceções.

Quando nos propomos a investigar a concepção de realeza de João Crisóstomo, um dos mais influentes líderes cristãos do Oriente na transição do século IV para o V, é visível o quanto o autor se afasta de qualquer compromisso com a agenda política eusebiana, pois, em sua opinião, o governo do imperador romano não comportava nada de divino ou sobrenatural, com exceção do antigo princípio formulado por Paulo, em sua Epístola aos romanos (13,1-4), segundo o qual toda autoridade constituída era proveniente de Deus, princípio este bastante genérico, por sinal. Contrapondo-se ao triunfalismo de Eusébio, João Crisóstomo recusava-se a considerar o governo do basileus a antecipação do reino de Deus sobre a Terra, embora tampouco fosse hostil ao Estado romano, o que o afastava igualmente da tradição apocalíptica que interpretava o domínio de Roma sobre o mundo como o governo de Satanás e de suas falanges. De acordo com João Crisóstomo, a monarquia não era uma instituição natural, pois o imperador não reinaria sobre os súditos devido a qualquer atributo inato, mas por ter sido eleito, vale dizer, escolhido por seus pares, encontrando-se, portanto, numa posição instável e sujeito à deposição. Por rejeitar a basileia e todos os símbolos de sacralidade que a constituíam, João não compartilha da opinião de Eusébio, razão pela qual merece certamente reparos a avaliação de Dvornik (1966, p. 697), para quem "o entusiasmo de Eusébio acerca das bênçãos da Pax Romana infectaram João Crisóstomo como haviam infectado muitos autores cristãos". Na verdade, ao longo de sua extensa obra, João nunca menciona a existência de um Imperium Christianum, como também poucas vezes faz alusão aos soberanos ou aos acontecimentos políticos do seu tempo, temas que não o interessam e aos quais não presta atenção, uma vez que a verdadeira cidadania à qual os cristãos aspiravam seria exercida apenas no céu e não sob a égide dos imperadores (SANDWELL, 2004, p. 38-41). Todavia, mesmo em face desse reconhecido desinteresse do autor pelos temas clássicos da política, incluindo a natureza da potestas imperial, que tanto ocupou alguns de seus contemporâneos, a exemplo de Temístio de Bizâncio, não julgamos correta a afirmação de Pasquato (2005, p. 783) segundo a qual, como resultado de seu envolvimento com o ascetismo, que o levou a afastar-se de qualquer compromisso com o aparato estatal, João não teria se notabilizado por uma atuação propriamente política, mas acima de tudo religiosa, o que nos impediria, ao fim e ao cabo, de extrair de sua obra qualquer conclusão sobre os fundamentos da basileia ou ao menos sobre a maneira pela qual o pregador encarava o ofício imperial. Julgamos que é justamente em virtude da inclinação de João Crisóstomo pela vida ascética que temos condições de recuperar, embora de modo um tanto ou quanto difuso, a sua concepção de realeza, como demonstra uma das primeiras - senão a primeira - de suas obras, o tratado Uma comparação entre o rei e o monge, escrito muito provavelmente logo após o autor ter deixado o didaskaleion de Libânio, por volta de 370. Nele, João nos oferece uma imagem da monarquia que contrasta agudamente, não apenas com a tradição política eusebiana, mais ou menos replicada por Temístio, mas também com o próprio cerimonial da basileia, que tendia a isolar cada vez mais o imperador, num processo de evidente sacralização, pois, segundo o autor, os monarcas não apenas seriam privados de qualquer dignidade sobrenatural, mas também exibiriam uma pletora de vícios que os afastariam da 
perfeição, esta, por sua vez, encarnada na figura dos monges que, na segunda metade do século IV, despontavam como personagens de relevo, em especial no ambiente sírio.

\section{A realeza monástica}

Em 386, ao ser ordenado presbítero da congregação de Antioquia, João Crisóstomo deu início a uma nova fase em sua carreira literária, cedo despontando como um pregador inspirado que nos legou cerca de novecentas homilias. Entretanto, antes de se afirmar como o mestre da prédica cristã, João já era conhecido como um eminente autor de tratados que versavam sobre as conveniências da vida religiosa, com destaque para o monacato que, em seu tempo, era prática corrente na Síria e no Egito. ${ }^{1}$ As obras dessa primeira fase encontram-se, portanto, marcadas pelo entusiasmo de João com relação à vida monástica, num momento em que, tendo completado sua formação superior em retórica, opta por se dedicar ao ascetismo, contrariando sua mãe, Antusa, que vislumbrava para o filho uma promissora carreira na administração pública, talvez como membro dos sacra scrinia. De início, João se une ao asketerion, um grupo de jovens dedicados ao estudo das Escrituras sob o comando de Diodoro, o futuro bispo de Tarso, e Cartério, personagem da qual não sabemos muito mais. Embora o asketerion não fosse um mosteiro, não dispondo, portanto, de sede fixa, o que obrigava seus integrantes a se reunirem nas residências para orar, interpretar a Bíblia e ouvir as preleções de Diodoro e Cartério, não resta dúvida de que o grupo, ao incentivar a observância da castidade e a renúncia aos prazeres mundanos, organizava-se segundo os parâmetros monásticos. Ao mesmo tempo, seus membros, inscritos numa lista oficial (o katalogos) e unidos por juramento, viam a si mesmos como irmãos, o que sugere a formação de uma irmandade com propósitos claramente ascéticos (KELLY, 1995, p. 18-19). Nesse ínterim, João é batizado por Melécio, um dos bispos de Antioquia à época, passando, em 371, à condição de lector, o primeiro passo de uma trajetória que o levaria, décadas mais tarde, a assumir a sé de Constantinopla.

Logo após o batismo de João, Melécio é obrigado a se refugiar na Armênia por conta da decisão de Valente de se instalar em Antioquia durante o inverno de 371/372. Sofrendo com a carência de quadros, os melecianos tentam ordenar João como presbítero, o que suscita uma veemente recusa por parte do candidato, hábil o suficiente para se eximir da responsabilidade.

\footnotetext{
Dentre os textos escritos por João Crisóstomo antes de iniciar sua carreira como pregador da congregação de Antioquia, contam-se, além da Comparação entre o rei e o monge, os seguintes: Contra os detratores da vida monástica, Sobre a compunção, Exortações a Teodoro que havia cedido, três livros A Estagírio, atormentado pelo demônio, Sobre o sacerdócio, $A$ uma viúva jovem, e Não se devem repetir as núpcias (MORESCHINI; NORELLI, 2000, p. 190-191). Neles, João Crisóstomo revela uma nítida inclinação pela prática do ascetismo, com destaque para o celibato e a castidade, temas que constituem uma autêntica obsessão para os autores cristãos da Antiguidade tardia, como comprova a abundância dos tratados dirigidos às virgens e às viúvas, bem como a profusão de relatos que convertem os monges, em especial os anacoretas, em heróis do cristianismo.
} 
Todavia, surpreendido com a ordenação iminente, João decide se retirar para os Montes Sílpios, a leste de Antioquia, a fim de se dedicar à vida monástica. Nos primeiros quatro anos, foi introduzido no treinamento ascético sob a supervisão de um monge sírio que orientava um grupo de postulantes agrupados em cabanas ou celas. Sua rotina incluía, como de praxe, orações individuais e comunitárias, estudo das Escrituras, meditação, trabalhos manuais (cultivo de plantas, confecção de cestos de palha) e refeições em comum. Encerrada essa fase preliminar, João se isola em uma caverna, observando uma ascese ainda mais rigorosa, marcada por noites insones consumidas no aprendizado das Escrituras e por longos períodos de jejum, o que compromete seu aparelho digestivo e seus rins (Pal. Dial, 5). Fustigado pela doença e estimulado pelo retorno de Melécio, em 378, logo após a morte de Valente, abatido pelos godos em Adrianópolis, João renuncia à vida monástica e regressa a Antioquia onde, em 381, é consagrado diácono e, cinco anos depois, presbítero (BRÄNDLE, 2003, p. 38-40). Mesmo obrigado deste então a rever sua posição sobre o monacato como a única modalidade capaz de proporcionar a elevação espiritual dos cristãos, João jamais abriu mão dos preceitos monásticos assimilados durante sua convivência com os integrantes do asketerion e os eremitas dos Montes Sílpios, o que anos mais tarde the renderia muitos problemas perante o Sínodo do Carvalho, responsável por sua deposição (HUNTER, 1988, p. 17). ${ }^{2}$

Data do período compreendido entre 368 e 378, década na qual João se encontrava diretamente envolvido com o ascetismo, a redação de um breve tratado intitulado Uma comparação entre o rei e o monge, que diversos autores consideram a primeira obra de João Crisóstomo, fruto muito provavelmente de um exercício escolar proposto por Diodoro aos seus discípulos do asketerion (BAUR, 1959, p. 115). ${ }^{3}$ Do ponto de vista da disposição dos argumentos, o opúsculo é composto sob a forma de comparação (súnkrisis), recurso literário-pedagógico bastante comum na escola dos gramáticos e dos rétores. Já do ponto de vista do gênero, a Comparatio é classificada como um protreptikós, um discurso de exaltação, cujas origens remontam à sofística grega do século V a. C. (HORNBLOWER; SPAWFORTH, 2012, p. 1228). No caso, a intenção de João Crisóstomo seria a de enaltecer a vida monástica como estratégia de persuasão dos companheiros que, como ele, faziam parte do asketerion, a exemplo de Teodoro e Máximo, mais tarde ordenados bispos de Mopsuéstia e de Selêucia Isauriana, respectivamente. Nele, o autor retoma um topos da literatura clássica bastante familiar aos autores cristãos: a comparação entre o rei-filósofo e o tirano tal como concebida por Sócrates e enunciada nos textos de Platão e Xenofonte (CARTER, 1958, p.

\footnotetext{
${ }^{2}$ Não obstante o esforço de Wendy Mayer (2006) no sentido de redimensionar o impacto da formação monástica no comportamento de João Crisóstomo como presbítero e, mais tarde, bispo de Constantinopla, ao consultarmos a lista de acusações apresentadas contra ele no Sínodo do Carvalho, em 403, é impossível não detectar em algumas delas a influência do ascetismo monástico, pois João é acusado de vender as placas de mármore adquiridas por Nectário para decorar a igreja de Santa Anastácia e de fazer suas refeições sozinho, ações que Paládio (Dial. 5; 12), seu principal biógrafo, atribui à sobriedade, moderação e ímpeto de caridade que sempre o inspiraram. O repertório completo das acusações pode ser consultado em Kelly (1995, p. 299-301).

${ }^{3} \mathrm{Em}$ 1952, J. Weyer, em uma dissertação intitulada De homiliis quae Joanni Chrysostomi falso attibuuntur, contrariava toda uma tradição da qual fazem Montfaucon e Migne ao propor que a Comparatio, em virtude da linguagem empregada, não era compatível com os demais textos de João Crisóstomo, colocando assim em suspeição a autenticidade da autoria. Todavia Hunter (1988), apoiando-se nos trabalhos de Aldama e Carter, empreendeu uma defesa convincente da tradição, sustentando que a Comparatio é um texto da lavra de João Crisóstomo. Para tanto, o autor evoca dois argumentos bastante convincentes: a) a identidade entre a Comparatio e outro tratado de João, intitulado Contra os detratores da vida monástica, de maneira que o segundo desenvolve em maior profundidade temas já contidos no primeiro; b) a presença, na Comparatio, de quatro passagens extraídas dos discursos de Libânio, professor de retórica de João Crisóstomo em Antioquia.
} 
367). João, no entanto, possui uma interpretação peculiar do assunto, pois, na obra, empenha-se em demonstrar que o verdadeiro filósofo é o monge, ao passo que o rei, não importando o quão virtuoso ele seja ou venha a ser, nunca conseguirá se equiparar ao monge, ou seja, nunca poderá aspirar à condição de filósofo. Nesse sentido, na Comparatio não encontramos, como seria de se esperar, um contraponto entre a modalidade perfeita e a degradada de governo, encarnadas na pessoa do rei-filósofo e do tirano, mas entre o governo das coisas humanas e o das coisas divinas, donde resulta que, conforme o autor, a realeza é, por si mesma, uma instituição menor quando comparada ao monacato, como nos revelam os atributos e poderes do rei, inferiores e por vezes opostos àqueles revestidos pelos monges.

Segundo João, muito embora o vulgo considere bem-aventurado aquele que "governa províncias, circula em carros esplêndidos e se apraz com o grito dos arautos e com um grande número de guarda-costas", esse tipo de comportamento, próprio dos que detêm o mando civil e militar, é efêmero e sem valor, pois, além de proporcionar infortúnios, não permite a elevação da alma, dificultando assim a absolvição do indivíduo perante o tribunal divino. O rei, com apenas um aceno de cabeça, é capaz de comandar generais, prefeitos, súditos e senadores, mas, privado da filosofia, é incapaz de controlar a si mesmo, de se manter ao abrigo das paixões e do gosto pela riqueza (Comparatio, 1). A despeito do diadema de ouro e pedras preciosas e do manto púrpura que ostenta, o rei é uma figura um tanto ou quanto patética, pois, ainda que seu corpo seja brilhante, sua alma carece de moderação, de autocontrole, o que o impede de guiar os homens no caminho da retidão. Já o monge, por conservar-se distante da ira, da inveja e dos prazeres mundanos, deveria ser, na opinião do autor, o comandante de "pessoas, terra, mar, cidades e soldados". No que se refere à destreza militar, o rei também seria inferior ao monge, pois enquanto o rei combateria os bárbaros com o objetivo de se apoderar de "territórios, montanhas ou riquezas", ou seja, por cobiça e desejo de exercer um poder injusto, o monge enfrentaria os demônios pela glória de Deus, livrando cidades e aldeias do erro (Comp. 2). Desse modo, o monge deteria uma potência mística (dynamis) que faltaria ao rei, pois, mediante suas preces, seria capaz de libertar as almas atormentadas pelos demônios, ao passo que o rei, se muito, conseguiria apenas remediar a penúria vivida pelos súditos mais pobres. Além disso, mesmo o rei, em situações de perigo extremo, seria obrigado a recorrer ao monge, como fez Ezequias, ao solicitar a intervenção miraculosa de Isaías no episódio do ataque de Senequeribe a Jerusalém, quando a cidade estava prestes a ser capturada pelos assírios. Na ocasião, o profeta teria rogado, no Templo, a lavé, que o atendeu, enviando uma chuva de setas sobre as tropas assírias (Comp. 4).

O cotidiano da corte, por sua vez, contribuiria diretamente para a corrupção da alma do soberano que, vivendo todo o tempo na companhia dos cortesãos, tenderia a absorver os defeitos de caráter destes últimos, despendendo seus dias e noites no consumo desenfreado de vinho (Comp. 2). Na realidade, uma das principais recriminações de João Crisóstomo dirigidas aos reis diz respeito ao desenfreio da sua conduta frente aos prazeres da vida, ao se excederem no beber, no comer e no dormir, o que exprime a sua inaptidão para o exercício da filosofia, uma vez que os filósofos (i.é, os monges) não apenas cultivam o aprimoramento do espírito, mas igualmente do 
corpo mediante a observância de hábitos que os habilitam a submeter as paixões, passando assim a privar do convívio regular com Deus, o comes supremo, poderíamos acrescentar, como vemos na passagem abaixo:

Se desejássemos examinar o intervalo noturno, nós veríamos o monge adornado com o louvor a Deus e preces, cantando muito mais cedo do que os pássaros, vivendo com os anjos, conversando com Deus, gozando dos bens celestes. Mas aquele que comanda muitas nações, povos e exércitos, que governa sobre muitas terras e mares, você veria sobre um divã, roncando. Pois o monge se alimenta de produtos que não demandam sono profundo, ao passo que comidas extravagantes levam o rei a dormir, e a bebida o mantém na cama mesmo durante o dia. Por essa razão, o monge tem comida e trajes moderados, e seus companheiros de mesa são atletas da virtude (Comp. 3).

No que se refere à promoção da justiça social, o rei, com suas decisões, revela-se profundamente injusto, pois, se ordena a remissão das taxas, beneficia muito mais os ricos do que os pobres. Por outro lado, se adota um regime pesado de taxação, arruína aqueles que pouco possuem, "varrendo as casas dos pobres como uma torrente e enchendo o campo de lamentos". Já seus coletores de impostos não têm por hábito apiedar-se dos anciãos, das viúvas ou dos órfãos, mas zombam deles sem cessar, exigindo dos agricultores que entreguem aquilo que a terra não produz. O monge, por sua vez, exibiria a mesma conduta tanto diante do pobre quanto do rico, curando ambos sem distinção e livrando-os igualmente dos antigos pecados por intermédio de úteis conselhos (Comp. 3).

Embora considere o ofício régio uma atividade que, por si mesma, induz o homem a renegar a virtude, João Crisóstomo admite que o rei, mediante o emprego da razão e da temperança, possa ser bom e justo, mas numa condição inferior à do monge. Segundo ele:

Mesmo se um rei filosofar, ele não será capaz de se aproximar nem de longe da beleza e bondade do monge. Pois mesmo em viagem o rei é oneroso aos súditos, quando reside nas cidades, seja em tempos de paz ou em tempos de guerra, quando extrai o tributo e organiza as tropas e convoca conscritos, quando conquista e quando é derrotado. Pois, quando é derrotado, ele satura seus súditos com os seus próprios infortúnios, mas quando vence, ele se torna insuportável, paramentando-se com troféus, tornando-se soberbo, 
concedendo aos seus soldados licença para pilhar, espoliar e insultar viajantes, sitiar cidades, arruinar as propriedades dos pobres [...] (Comp. 3).

Se, em vida, o rei e o monge não partilham o mesmo destino, na morte a diferença entre eles se torna flagrante, na medida em que o rei, vítima de algum outro tirano, se tornaria uma figura digna de pena, ao passo que o monge, ao morrer, se tornaria um ícone de salvação, levando muitos a imitar suas boas obras. De acordo com João Crisóstomo, se fosse permitido indagar sobre o destino de ambos,

[...] veríamos o monge, glorioso e admirado, sendo levado pelas nuvens para encontrar o Senhor no paraíso, seguindo o exemplo e as instruções de todas as virtudes e desse modo santo de vida. Mas mesmo que pareça ter o rei administrado seu reino com equidade e filantropia (o que é muito raro), ele receberá o grau menor de salvação e de honra. Pois eles não são iguais: não, não são iguais um bom rei e o monge que vive inteiramente a serviço de Deus. Mas se o rei demonstrar ter sido vil e mal-comportado, enchendo a terra com muitos males, quem pode dizer as calamidades que o afligirão queimado, fustigado, torturado, sofrendo coisas que não podem ser descritas com palavras, nem de fato suportadas? [...] Por essa razão, onde quer que vejam um homem rico em trajes nobres, adornado com ouro, sendo transportado num carro, fazendo procissões esplêndidas, não o considerem bendito. Pois a riqueza é transitória, e o que parece ser bom, perece ao longo da vida (Comp. 4).

A comparação entre o rei e o monge formulada por João Crisóstomo nos sugere, em primeiro lugar, que a pompa e a magnificência do poder imperial não atraíam, em absoluto, o jovem asceta, que se afastava assim de qualquer compromisso com a basileia, rejeitando a ideia, corrente à época, de que o poder imperial comportasse uma sacralidade intrínseca e que o próprio imperador, na condição de êmulo de Cristo, fosse o principal responsável por edificar os súditos, insuflando neles o apego à virtude. Segundo o autor, a realeza, além de não comportar nada de especial, seria por ela mesma uma instituição que estimulava, em seus representantes, um comportamento indigno, inadequado, vicioso, levando assim às últimas consequências os argumentos estoicos acerca do caráter corruptor e licencioso do poder. Mesmo nos raros casos em que o rei se mostrasse inclinado à justiça e à clemência, isso não seria suficiente para torná-lo superior aos monges, que deteriam, em qualquer circunstância, a primazia. O que se delineia aqui, por meio de um topos literário-filosófico antiquíssimo, é a resposta de João Crisóstomo a uma questão que, em 
seu tempo, gerava a mais acesa polêmica: ao basileus, paramentado com todas as suas insígnias e convertido em interlocutor privilegiado da divindade judaico-cristã, seria autorizado intervir na Igreja, instituição composta por uma pletora de sujeitos de poder que também aspiravam ao comando monárquico de suas próprias congregações, como eram os bispos? Ou, dito em outros termos, a competência civil dos imperadores bastaria para torná-los paradigmas de uma crença que se apresentava como um sistema filosófico? Segundo João, a resposta era forçosamente negativa, uma vez que, no limite, os reis teriam de recorrer aos monges, cujos poderes sobrenaturais os habilitavam, inclusive, a defender a própria realeza.

Refletindo acerca das condições históricas nas quais a Comparatio foi produzida, verificamos que os anos de juventude de João Crisóstomo transcorreram numa conjuntura bastante desfavorável para os cristãos, em geral, e para os nicenos, em particular. De fato, no início da adolescência, por volta dos quatorze anos, João já teria maturidade suficiente para compreender os riscos que o governo de um soberano como Juliano representava para o cristianismo. Não obstante a morte precoce do imperador, em 363, em meio à campanha contra os persas, os anos que se seguiram não foram de paz para os cristãos, como seria de se esperar, pois, no Oriente, a ascensão de Valente precipitava novamente a Igreja em acerba discórdia. Adepto do homeísmo, uma das subdivisões do arianismo, ${ }^{4}$ Valente adotou desde o início uma atitude de aberta hostilidade para com os nicenos, desencadeando com isso inúmeros conflitos nas igrejas locais. Em Antioquia, devido à ascensão do soberano, Euzoio, o antigo bispo ariano indicado por Constâncio II, assume novamente a dianteira, reavendo o controle das igrejas e confrontando a autoridade de Melécio e Paulino, os dois bispos nicenos que, por sua vez, rivalizam entre si. Por força de um decreto emitido em maio de 365, que anulava a permissão de retorno às antigas sés concedida por Juliano aos bispos exilados sob Constâncio, Melécio é obrigado a deixar a cidade, retornando um pouco depois, quando Valente, ocupado em dar combate aos godos, tem sua atenção desviada para assuntos mais urgentes. Entre 371 e 372, no entanto, com o recrudescimento da perseguição imperial aos nicenos e a instalação de Valente em Antioquia, Melécio é novamente exilado. No decorrer dessas idas e vindas, seus partidários, liderados por Flaviano e Diodoro, se mantêm leais ao bispo, celebrando o ofício religioso nas grutas aos pés dos Montes Sílpios, nas margens do Orontes ou no Campo de Marte, localizado diante da Porta do Norte (SOLER, 2006, p. 145; DOWNEY, 1961, p. 410-411). Dentre os "melecianos" ativos nesse período, encontrava-se João Crisóstomo, que, em face das condições adversas pelas quais passava sua congregação, não poderia, decerto, nutrir maior apreço pela autoridade imperial. Na avaliação de Hunter (1988, p. 26), ao redigir a Comparatio, a intenção de João Crisóstomo seria se opor a Libânio, seu antigo professor, e a Juliano, razão pela qual o autor teria sido tão enfático em assinalar os vícios da realeza. A despeito dos ataques que, em mais de uma oportunidade, João desferiu contra Juliano, como vemos no Discurso sobre o santo Bábilas e contra os gregos e na Demonstração contra os pagãos que Cristo é Deus, não nos parece de todo coerente supor que, na Comparatio, o alvo

\footnotetext{
${ }^{4}$ De acordo com a tendência homeísta, o Filho seria semelhante, mas não idêntico em substância (homoousios) ao Pai, como preconizava a fórmula de fé estabelecida no Concílio de Rimini, em 359, por manobra de Valente de Mursa, um dos conselheiros de Constâncio II (BERARDINO, 2002, p. 1223-1224).
} 
principal fosse o imperador, em virtude da insistência de João em censurar o aparato cênico da basileia (diadema, manto, carruagem, arautos), algo que Juliano, em seu curto governo, também fez questão de rejeitar. Muito embora a experiência sob Juliano tenha certamente concorrido para minar a crença de João Crisóstomo nas pretensões elevadas do basileus, a bem da verdade, no que diz respeito à comunidade nicena de Antioquia, o governo de Valente foi muito mais nocivo, como comprovam os exílios sofridos por Melécio.

\section{Santos, heróis e baderneiros}

Aclarados os motivos pelos quais João Crisóstomo não poderia nutrir uma imagem favorável acerca do poder imperial, caberia a esta altura nos interrogarmos a respeito da sua predileção pelos monges como os heróis da fé cristã, uma vez que os bispos disputavam a mesma posição. Uma explicação plausível foi formulada por Carter (1958, p. 367), para quem os monges se ajustavam bastante bem aos propósitos de João em construir um modelo antitético de realeza pelo fato de manifestarem, eles mesmos, uma notória indiferença para com o Estado, optando por um estilo de vida que os colocava ao abrigo das autoridades e, mais que isso, os subtraía da incômoda exigência de contribuir com o Erário, como comprova a aplicação do vocábulo anachoresis a algumas modalidades de eremitismo (MARAVAL, 1995, p. 722). Originalmente empregado para designar a fuga dos devedores falidos rumo ao deserto, numa tentativa desesperada de iludir o fisco, o substantivo anacorese, no século IV, passa a fazer referência ao estilo de vida dos monges do Delta e alhures, tendo sido popularizado por Atanásio, na sua Vida de Santo Antão. Uma importante evidência do quanto o monacato poderia ser, em termos econômicos, prejudicial aos interesses do Estado advém de duas leis emanadas por Valente, em 373 e 375, por meio das quais o imperador, insatisfeito com o déficit na arrecadação e a escassez de mão de obra por conta tanto dos privilégios de longa data concedidos à hierarquia sacerdotal quanto pelo comportamento refratário dos monges determina o regresso imediato à cúria urbana daqueles que, integrando a ordem dos decuriões, haviam se evadido para lugares desconhecidos, bem como a inscrição compulsória dos monges provenientes de outras categorias sociais nas fileiras do exército (LENSKY, 2004, p. 99-100). ${ }^{5}$

De acordo com Teja (1989, p. 85 e ss.), ainda que carente de organização, o movimento monástico trairia, nas suas origens, uma atitude de rebelião e de protesto social, o que explicaria o fato de encontramos, entre seus adeptos, deserdados e desarraigados de todas as cepas, incluindo os facínoras, o que nos alerta para as implicações sociopolíticas do monacato ou, melhor dizendo,

\footnotetext{
${ }^{5} \mathrm{Em}$ ambas as ocasiões, tudo leva a crer que Valente se dirigisse aos monges defensores do homoousios, o que contribuía para aumentar o atrito entre a casa imperial e os setores da Igreja fiéis ao credo proclamado em Niceia. A primeira lei encontra-se conservada no $C$. Th. (12.1.63). Da segunda, não possuímos o texto, cuja notícia nos é fornecida por Jerônimo, na sua Crônica.
} 
para a sua capacidade em produzir tensão e conflito, a despeito de toda a retórica que insistia no papel dos monges como mediadores privilegiados entre o humano e o divino. Adotando um comportamento arredio, recalcitrante e por vezes belicoso, os monges nem sempre eram celebrados como líderes providenciais aos quais toda a comunidade acorreria em busca de proteção e auxílio, como nos induz a concluir Peter Brown (1971), em seu célebre artigo sobre a emergência da crença no homem divino, replicando assim, de certa maneira, a própria visão indulgente de João Crisóstomo, para quem os monges seriam os protetores das aldeias e cidades, o socorro dos pobres e dos ricos, os baluartes divinos da realeza, embora caminhassem sozinhos, adotando uma postura pacata e humilde (Comp. 4). Essa representação heroica dos monges contrasta, em diversos aspectos, com aquilo que sabemos acerca do movimento monástico na segunda metade do século IV, ao menos na Síria, onde vigorava, em diversos segmentos, certa desconfiança em relação aos monges, num contexto em que o monacato, em plena expansão, ainda era visto como algo novo, carecendo, portanto, de maior estabilidade perante as instituições estatais e eclesiásticas, fragilidade que o tratado de João Crisóstomo tenta, na medida do possível, reparar (LEROUX, 1975, p. 128-129).

$\mathrm{Na}$ Síria, os ascetas eram figuras que não raro suscitavam, na população, muito mais temor do que respeito. Habitando as regiões montanhosas e desérticas a céu aberto, expostos às intempéries e aos rigores do frio e do calor, alimentando-se de raízes e frutos selvagens, portando pouca ou nenhuma vestimenta, trazendo os cabelos alvoroçados e as unhas sem aparar, os monges assemelhavam-se, para alguns, a aves de rapina e não a seres humanos (BROCK, 1973, p. 11-12). Uma das características que distinguiam os ascetas sírios dos egípcios era justamente o investimento excessivo na mortificação do corpo mediante o emprego de pesadas correntes de ferro presas ao pescoço, aos rins ou às mãos que obrigavam os portadores a permanecer todo o tempo curvados, acentuando-se assim seus traços animalescos (FESTUGIÈRE, 1959, p. 293). Agrupados em bandos itinerantes, os ascetas sírios costumavam atrair, em seus deslocamentos, uma multidão de seguidores, dentre os quais desocupados e bandoleiros, causando temor aos citadinos, que não hesitavam em cerrar as portas da cidade ao mínimo sinal de sua aproximação, como certa vez fizeram os habitantes de Palmira diante da chegada de Alexandre Acemeta e sua comitiva de 400 pessoas (BROWN, 1971, p. 84). Em Antioquia, os pais mostravam-se exasperados com o comportamento desleal dos eremitas, acusando-os de descer os Montes Sílpios com o propósito de persuadir os jovens de boa família a abraçar a vida monástica e de desviá-los de uma carreira promissora na administração pública, razão pela qual os pais tentavam a todo custo impedir a pregação dos monges. ${ }^{6}$ Isso sem mencionar a frequente participação dos monges em conflitos envolvendo pagãos e judeus, como vemos no episódio da destruição do santuário de Zeus Belos, em Apameia, o que representava uma ameaça constante à ordem pública, a ponto de Teodósio, em uma lei de 390 (C. Th. 16, 3, 1), determinar que os monges fossem banidos para os desertos e lugares desabitados a fim de diminuir os distúrbios nas cidades e aldeias.

\footnotetext{
${ }^{6}$ A animosidade das famílias de Antioquia contra a atuação missionária dos monges estimulou João Crisóstomo a escrever, na sequência da Comparatio, um tratado mais extenso intitulado Contra os opositores da vida monástica, no qual se dedicava a refutar as críticas lançadas contra os anacoretas dos Montes Sílpios (LIEBESCHUERTZ, 2011, p. 109).
} 
No que diz respeito às autoridades eclesiásticas, estas, no início, não se mostraram inteiramente confortáveis diante do súbito florescimento do monacato, modalidade de prática religiosa nascida em meios laicos que os bispos desde cedo se esforçaram por colocar sob sua tutela, nem sempre com sucesso. As tensões e os conflitos de autoridade entre monges e bispos constituem, sem dúvida, um dos capítulos mais dinâmicos da História do Cristianismo na Antiguidade Tardia. ${ }^{7}$ À parte os anacoretas e os cenobitas, que não tardaram a ter a sua memória perpetuada em obras de grande circulação no Império tardio, a exemplo da Vida de Santo Antão, à qual já aludimos, e das diversas versões em copta, em grego e em latim da biografia de Pacômio, os ditos sarabaítas, ou seja, aqueles que optavam por exercer um ascetismo, por assim dizer, errante, parecem ter sofrido uma censura eclesiástica inclemente que contribuiu para reforçar a reputação duvidosa dos monges sírios (RUBENSON, 2008, p. 643). Na segunda metade do século IV, os choques entre os monges e os representantes da hierarquia eclesiástica deram ensejo, nos territórios da Mesopotâmia, Síria-Palestina e Ásia Menor à emergência do messalianismo, uma corrente de rigorismo ascético cujos adeptos, denominados, em siríaco, messalianos e, em grego, euquitas, isto é, "aqueles que oram", sustentavam o princípio segundo o qual cada homem abrigava, em sua alma, um demônio que não poderia ser expulso pelo batismo, mas apenas por meio de uma atitude de contínua oração, como havia recomendado Paulo, na sua Epístola aos Tessalonicenses $(5,17)$, única maneira de infundir, no crente, a centelha do Espírito Santo, que o redimiria de seus pecados e imperfeições. Inspirados por sonhos e visões, os messalianos eram reputados como profetas, anunciando profundas reformas na ordem social vigente. Em termos disciplinares, rejeitavam qualquer atividade regular, mesmo que em prol da caridade, preferindo esmolar, além de negarem a hierarquia eclesiástica e os sacramentos, o que não tardou a despertar a má-vontade das autoridades episcopais. Epifânio, bispo de Salamina, em seu Panarion, um inventário das heresias ou "doenças espirituais" conhecidas desde a época de Simão, o Mago até fins do século IV, registra o messalianismo como a última delas. Em 381, num concílio celebrado em Antioquia sob a presidência de Flaviano, os messalianos foram condenados pela primeira vez (MARAVAL, 1995, p. 738-9), ao que tudo leva a crer, sem êxito, pois condenações sucessivas se repetem em Constantinopla (426) e Éfeso (431), indício da dificuldade da Igreja em conter o movimento (BERARDINO, 2002, p. 933).

\footnotetext{
7 Em 451, no Concílio de Calcedônia, os bispos conciliares ainda se encontravam às voltas com a excessiva independência dos monges, o que os leva a pronunciar a seguinte decisão, contida no cânone quarto: "Na medida em que certas pessoas, sob o pretexto do monacato, criam confusão nas igrejas e nos assuntos políticos, comportando-se de modo promíscuo nas cidades e ao mesmo tempo buscando estabelecer mosteiros para eles mesmos, decreta-se que ninguém em nenhum lugar deve fundar um mosteiro ou um oratório contrário ao desejo do bispo da cidade. E que os monges em cada cidade e distrito se submetam aos bispos e abracem um curso tranquilo de vida, e se dediquem apenas ao jejum e à oração, permanecendo todo o tempo nos lugares em que se estabeleceram" (SCHAFF, WACE, 2004, p. 270).
} 


\section{Considerações finais}

Todos os acontecimentos acima descritos nos sugerem que os monges sírios, na segunda metade do século IV, não gozavam do prestígio e da reputação contidos numa literatura posterior destinada claramente a enaltecê-los, a exemplo da História Religiosa, de Teodoreto de Ciro, uma compilação de breves notícias biográficas sobre os homens divinos da Síria e da Palestina composta na primeira metade do século V. À época em que João Crisóstomo elabora sua Comparatio, a súbita ascensão do monacato gera apreensão e desconfiança nos contemporâneos, como sói ocorrer com toda experiência que proponha práticas sociais por demais inovadoras diante dos padrões convencionais, motivo pelo qual os monges, em diversas ocasiões, foram tratados como desviantes, como indivíduos que, subvertendo os códigos tradicionais de conduta, traziam certo perigo para a comunidade. Partidário da causa dos monges, João Crisóstomo, ele mesmo imbuído de uma profunda admiração pelo ascetismo, elabora o seu tratado, no qual busca criar uma imagem, digamos, mais palatável daqueles que decidiram romper com as convenções do mundo para dedicar-se à vida religiosa. Com esse propósito, recupera um argumento bastante conhecido em seu tempo: o do cristianismo como filosofia, tomada aqui não no sentido de uma corrente intelectual de especulação sobre as realidades da physis ou sobre as propriedades do logos, mas como um estilo de vida por meio do qual buscava-se a elevação espiritual, fim igualmente almejado pelos sábios pagãos dos mais distintos matizes (CANER, 2012, p. 593). Na condição de amantes da filosofia, do verdadeiro conhecimento, os monges decidiram viver uma vida solitária e livre das paixões carnais, distinguindo-se pelo perfeito domínio de si mesmos, ainda que às custas da degradação corporal. Tendo cumprido seu treinamento espiritual, convertiam-se em agentes capazes de interceder em benefício tanto dos ricos quanto dos pobres e de operar milagres, ou seja, passavam a ser detentores de um poder que se sobrepunha ao do próprio basileus.

Mediante a análise da Comparatio, percebemos o quanto o autor se distanciava do ponto de vista segundo o qual a basileia seria uma realeza sagrada e o basileus, a mímesis terrena de Cristo, alguém responsável por proteger e difundir a verdadeira fé num momento em que a fusão do Império Romano com a Igreja parecia um fato consumado. Muito embora tais concepções, bastante caras a uma teologia política então emergente, fossem voz corrente na época tardia, sendo reiteradas tanto mediante uma retórica sustentada por panegiristas incumbidos de enaltecer os feitos do imperador quanto por símbolos e rituais do poder cada dia mais sofisticados, inclusive com a anuência explícita de membros da hierarquia eclesiástica, é preciso reconhecer que nem todos cristãos possuíam uma imagem tão elevada do ofício régio, recusando-se a aceitar a ideia de que a opção de Constantino por Cristo e não por Apolo tenha significado, no fim das contas, uma alteração sensível da natureza do poder imperial. João Crisóstomo se revela, assim, um dos pensadores mais céticos acerca da possibilidade de instauração de um Império Romano Cristão, no sentido de um território cuja população pudesse ser cristianizada mediante a direta intervenção dos imperadores, como se a prerrogativa da empresa evangelizadora coubesse ao basileus e não aos 
legítimos representantes de Cristo, como eram os bispos, os mártires, os confessores, as virgens e os monges. Ao longo de toda a sua carreira como pregador, João jamais abriu mão de suas convicções políticas, a ponto de, numa das homilias dedicadas à exegese da Segunda Carta aos Coríntios, pronunciada em Antioquia já sob o governo de Teodósio, um imperador francamente comprometido com o credo de Niceia, reafirmar a primazia da autoridade eclesiástica sobre a autoridade civil, pois esta última, ao contrário do que se supunha, não teria nada a ensinar sobre a autêntica sabedoria, ou seja, "sobre o que é alma, o mundo, o que advirá no futuro e para onde havemos de migrar". Além disso, considerando que a morte não é o fim da vida, aqueles que prezavam as coisas de Deus eram condutores do povo mais dignos do que os "cingidos com o diadema", numa clara alusão ao basileus (In 2Cor, XV, 12). Na medida em que os cristãos eram meros passageiros sobre a Terra, somente a Igreja tinha condições de orientá-los rumo à Cidade Celeste, razão pela qual, ao longo de toda a sua vida, João Crisóstomo se recusou a reconhecer que o poder imperial, fruto da ambição e refém de todos os vícios, pudesse se manter como um agente eficaz da cristianização.

\section{Referências}

\section{Documentação primária impressa}

CHRYSOSTOM. Homilies on the epistles of Paul to the Corinthians. Peabody: Hendrickson, 2004.

EUSEBIO DE CESAREA. Vida de Constantino. Introducción, traducción y notas de Martín Gurruchaga. Madrid: Gredos, 1994.

JOHN CHRYSOSTOM. A comparison between a king and a monk. Against the opponents of the monastic life. Translated with an introduction by David G. Hunter. Lewiston: The Edwin Meller Press, 1988.

PALLADIUS. Dialogue on the life of St. John Chrysostom. Translated by Johannes Quasten. Mahwah: Paulist Press, 1985.

SÃO JOÃO CRISÓSTOMO. Comentário às cartas de São Paulo. São Paulo: Paulus, 2010. v. 2.

\section{Bibliografia}

BAUR, C. John Chrysostom and his time. Westmister: Newman Press, 1959.

BERARDINO, A. (Ed.). Dicionário patrístico e de antigüidades cristãs. São Paulo: Paulus, 2002. 
BíBLIA. Português. Bíblia de Jerusalém. Edição coordenada por Gilberto Gorgulho, Ivo Storniolo e Ana Flora Anderson. São Paulo: Sociedade Bíblica Católica Internacional, 1997

BRÄNDLE, R. Jean Chrysostome, Saint Jean Bouche d'or (349-407): Christianisme et politique au IVe siècle. Paris: Du Cerf, 2003.

BROCK, S. P. Early Syrian asceticism. Numen, v. 20, n. 1, p. 1-19, 1973.

BROWN, P. The rise and function of the holy man. The Journal of Roman Studies, v. 61, p. 80-101, 1971.

CANER, D. F. Not of this world: the invention of monasticism. In: ROUSSEAU, P. (Ed.). A companion to Late Antiquity. Oxford: Wiley-Blackwell, 2012. p. 589-600.

CARTER, R. E. Sain John Chrysostom's rhetorical use of Socratic distinction between kinghip and tyranny. Traditio, n. 14, p. 367-370, 1958.

DOWNEY, G. A history of Antioch in Syria. Princeton: Princeton University Press, 1961.

DRAKE, H. Church and Empire. In: HARVEY, S. A.; HUNTER, D. G. (Ed.). The Oxford handbook of Early Christian studies. Oxford: Oxford University Press, 2010. p. 446-464.

DVORNIK, F. Early Christian and Byzantine political philosophy. Washington: The Dumbarton Oak Center for Byzantine Studies, 1966. v. 2.

FESTUGIÈRE, A. J. Antioche païenne et chrétienne: Libanius, Chrysostome et les moines de Syrie. Paris: E. de Boccard, 1959.

GONZÁLEZ SALINERO, R. El antijudaísmo cristiano occidental (siglos IV y V). Madrid: Trotta, 2000.

HORNBLOWER, S.; SPAWFORTH, A. (Ed.). The Oxford classical dictionary. Oxford: Oxford University Press, 2012.

HUNTER, D. G. Introduction. In: JOHN CHRYSOSTOM. A comparison between a king and a monk. Against the opponents of the monastic life. Lewiston: The Edwin Mellen Press, 1988. p. 1-68.

KELLY, J. N. D. Golden Mouth: the story of John Chrysostom - ascetic, preacher, bishop. London: Duckworth, 1995.

LENSKY, N. Valens and the monks: cudgeling and conscription as a means of social control. Dumbarton Oak Papers, v. 58, p. 93-117, 2004.

LEROUX, J. M. Saint Jean Chrysostome et le monachisme. In: KANNENGIESSER, C. (Ed.). Jean Chrysostome et Augustin. Paris: Beauchesne, 1975. p. 125-144.

LIEBESCHUETZ, J. H. W. G. Ambrose and John Chrysostom. Oxford: Oxford University Press, 2011.

MARAVAL, P. Le monachisme oriental. In: MAYEUR, J. et al. Histoire du Christianisme. Paris: Desclée, 1995. t. 2, p. 719-745.

MAYER, W. What does it mean to say that John Chrysostom was a monk ? Studia Patristica, v. 41, p. 451-455, 2006. 
MONTEFIORE, S. Jerusalém, a biografia. São Paulo: Companhia das Letras, 2013.

MORESCHINI, C.; NORELLI, E. História da literatura cristã antiga grega e latina. São Paulo: Loyola, 2000.

PASQUATO, PASQUATO, O. Giovanni Crisostomo e I'Impero Romano. In: INCONTRO DI STUDIOSI DELL'ANTICHITÀ CRISTIANA: Giovanni Crisostomo: Oriente e Occidente tra IV e V secolo, 33., 2004, Rome. Roma: Institutum Patristicum Augustinianum, 2005. p. 781-798.

QUASTEN, J. Patrology. Notre Dame: Christian Classics, 1949. v. I.

RUBENSON, S. Ascetiscism and monasticism, I: Eastern. In: NOBLE, T.; SMITH, J. The Cambridge History of Christianity. Cambridge: Cambridge University Press, 2008. p. 637-668.

SANDWELL, I. Christian self-definition in the fourth century AD: John Chrysostom on Christianity, imperial rule and the city. In: SANDWELL, I.; HUSKINSON, J. (Ed.). Culture and society in Later Roman Antioch. Oxford: Oxbow Books, 2004. p. 35-58.

SCHAFF, P.; WACE, H. (Ed.). The seven ecumenical councils. Peabody: Hendrickson, 2004. v. 14.

SILVA, G. V. da. Constâncio II, o Anticristo: Hilário de Poitiers e a construção da imagem imperial. Dimensões, v. 15, p. 219-235, 2003a.

SILVA, G. V. da. Reis,santos e feiticeiros: Constâncio II e os fundamentos místicos da basileia (337361). Vitória: Edufes, 2003.

SILVA, G. V. da; MARVILLA, M. De laudibus Constantini; o discurso de Eusébio de Cesaréia sobre a realeza. Dimensões, v. 18, p. 384-392, 2006.

SOLER, E. Le sacré et le salut à Antioche au IVe siècle apr. J.-C. Beyrouth: Institut Français du Proche-Orient, 2006.

TEJA, R. Monacato e história social: los orígenes del monacato y la sociedad del Bajo Imperio romano. In: HIDALGO DE LA VEGA, M. J. (Ed.). Homenaje a Marcelo Vigil Pascual. Salamanca: Universidad de Salamanca, 1989. p. 81-96.

Recebido em 18.07.2015 - aprovado em 07.10.2015 